\title{
The Influence of the Parent Offspring Relationship on Young People's Career Preferences
}

\section{La Influencia de la Relación Paterno-Filial en las Preferencias de Carrera de los Jóvenes}

\author{
Aharon Tziner, Gali Loberman, Ziv Dekel, and Gil Sharoni \\ Netanya Academic College
}

\begin{abstract}
This study examined the connection between the interpersonal relationship between parents and their offspring and the career preferences of the younger generation. While earlier studies suggest that the family plays a major role in young people's career choices, the specific dynamics of this influence have received very little research attention. We hypothesized that a high-quality parent-offspring relationship would be associated with a similarity between the parents' careers and job characteristics and their son/daughter's preferences for their future career. The sample consisted of 280 participants: $14612^{\text {th }}$ grade students and 134 university students. No significant correlation was found between the quality of the parent-offspring relationship and the similarity of careers. However, among participants reporting a highquality relationship with their parents, a positive correlation was found between the parents' job characteristics and their children's desired job characteristics. The results therefore indicate that the parental influence on young people's career preferences is mediated by the quality of the parent-offspring relationship. Keywords: parent offspring relationship, career preferences, joung people, job characteristics.
\end{abstract}

\begin{abstract}
Resumen. Este estudio examinó la influencia de la relación interpersonal entre padres e hijos y las preferencias de carrera de la generación más joven. Mientras que estudios anteriores sugieren que la familia juega un papel importante en la elección de carrera de los jóvenes, la dinámica específica de esta influencia ha recibido muy poca atención en la investigación. Nosotros hipotetizamos que una relación paternofilial de alta calidad se asociaría con una similitud entre las características de los puestos y carreras de los padres y las preferencias de sus hijos sobre sus futuras carreras. La muestra estaba compuesta por 280 participantes: 146 estudiantes de $12^{\circ}$ grado y 134 estudiantes universitarios. No se encontró correlación significativa entre la calidad de la relación padres-hijos y la similitud de las carreras. Sin embargo, entre los participantes que informaron de una relación de alta calidad, existe una correlación positiva entre las características del puesto de los padres y las características del puesto deseadas por sus hijos. Los resultados indican que la influencia de los padres en las preferencias profesionales de los jóvenes está mediada por la calidad de la relación padres-hijos.

Palabras clave: relación paterno-filiales, preferencias de carrera, jóvenes, características del puesto.
\end{abstract}

For most people, meaning in life is strongly linked to career goals, or to the various rewards that can be obtained by means of a career, i.e., money, status, and a sense of belonging. By creating social benefits, careers fulfill individual aspirations and afford meaning to one's life. As one's career can therefore be viewed as a key means of achieving self-realization, the embodiment of the meaning of life (Krau, 1997; Robertson, 1990; Rogers, 1978), career choices are of paramount importance. Career decisions often involve dynamic interactions between abilities, work values, occupational stereotypes and expectations, areas of interest, personality, and a variety of other factors, including the need or willingness to assume risks, edu-

Correspondence concerning this article should be addressed to: Aharon Tziner, School of Behavioral Sciences, Netanya Academic College, 1 University St., Kiryat Yitzhak Rabin, Netanya 42365, Israel. E-mail:atziner@netanya.ac.il cational achievements, status, ambition, talents, chance opportunities, and family influence (Miller, Wells, Springer \& Cowger, 2003). In addition, exploration is considered not only an important factor in identity development during adolescence, but a central process in career development as well (Super, 1990). While the individual acquires basic skills and a sense of independence in early adolescence, in later adolescence weaknesses and abilities are clarified, enabling the youngster to identify the strengths and capabilities that can ensure successful pursuit of professional/career goals (Dietrich \& Kracke, 2009). Young people's aspirations are generally expressed in terms of an image of the future, which must then be transformed into an action plan. Failure to realize one's aspirations is likely to be attributable to a failure to meet the demands of the surroundings and adjust to the developmental requirements that lead to the materialization of those aspirations. Thus, when an adult 
encounters adjustment difficulties, they may very well emanate from career challenges (Krau, 1997).

Research indicates that a number of factors influence youngsters' career aspirations, among them family relationships (Wahl \& Blackhurst, 2000). Moreover, young adults are more likely to freely explore career options when their parents grant them autonomy, support, and gradual independence, and waive the obligation of intergenerational professional choices (Crockett \& Bingham, 2000; Larson, 1995).

\section{Parental influence on career choice}

Despite the strong influence of peers during adolescence, parents continue to play a major role in the psychosocial development and adjustment of their children (Lamborn, Mounts, Steinberg, \& Dornbusch, 1991; Noller, 1994), and especially in regard to their career development (e.g., Kracke, 1997; PalladinoSchultheiss \& Blustein, 1994; Young, 1994). A substantial body of research literature affirms the relationship between a number of family variables and career development outcomes. Among these are parental attachment (e.g., Ketterson \& Blustein, 1997) and parental support (e.g., Wall, Covell, \& Maclntyre, 1999), as well as such career-related variables as vocational aspiration and achievement (Rainey \& Borders, 1997), career decisiveness (López \& Andrews, 1987), career exploration (Felsman \& Blustein, 1999; Kracke, 1997), career commitment (Blustein, Walbridge, Friedlander, \& Palladino, 1991), career self-efficacy (O’Brien, 1996), and career orientation (Tang, Fouad, $\&$ Smith, 1999). Studies suggest that family variables are broad ranging, influencing a number of career outcomes and persisting over time. In other words, many of the family variables that influence young people's career choices are deeply embedded in long-term processes such as parental attachment.

Research has shown that young adults speak most frequently about career issues with their parents (Otto, 2000), and name parents as a major influence during educational and career transitions (Mortimer, ZimmerGembeck, Holmes, \& Shanahan, 2002) and the choice of a vocation. The vast majority of studies that have sought to characterize this influence have addressed general aspects of the parent-offspring relationship, such as attachment (Blustein et al., 1991), individuation (Grotevant \& Cooper, 1988), parenting styles (Tracey, Lent, Brown, Soresi, \& Nota, 2006), and family climate and dysfunction (Hargrove, Inman, \& Crane, 2005; Ryan, Solberg, \& Brown, 1996). Findings indicate that a secure attachment style, individuation in the parent-offspring relationship, and authoritative parenting are linked to more career exploration activities (Grotevant \& Cooper, 1988; Kracke, 1997; Vignoli, Croity-Belz, Chapeland, de Fillipis, \& Garcia, 2005), higher career self-efficacy (Guay,
Senecal, Gauthier, \& Fernet, 2003; Lim \& Loo, 2003; Ryan et al., 1996), and earlier development of vocational identity (Johnson, Buboltz, \& Nichols, 1999; Tracey et al., 2006). On the other hand, family conflict and dysfunction have been found to be negatively associated with career self-efficacy and vocational identity development (Hargrove, Creagh, \& Burgess, 2002; Johnson et al., 1999; Ryan et al., 1996).

Several interview-based studies have explored the parental behaviors which young people perceive to be influential in their career development (e.g., Phillips, Blustein, Jobin-Davis, \& White, 2002; Phillips, Christopher-Sisk, \& Gravino, 2001; Schultheiss, Kress, Manzi, \& Glasscock, 2001). The results suggest three facets of parental behavior that are specifically directed to the younger generation's choice of career (Chope, 2005). The first is perceived parental support, which corresponds to the results of survey research, indicating that the more young people feel supported by their parents, the more they engage in career exploration activities. The second is autonomy granting, that is, allowing offspring to make their own choices while offering orientation and instrumental support (e.g., help in writing applications) if needed (Phillips et al., 2001). The third behavior is encouraging youngsters to explore vocational interests and abilities, as well as occupational options, and helping them to reflect on relevant career choice experiences (Schultheiss et al., 2001). Young people reported that these behaviors in particular strongly promoted their motivation to engage in the career preparation process (Phillips et al., 2002). However, some respondents indicated that their parents controlled their career actions and choices too much (Schultheiss et al., 2001). The offspring in these families were found to be more passive in the process of career preparation.

Blustein (2004) cites Super (1957) who, more than five decades ago, wrote eloquently about the role of such factors as social class, economic conditions, and family relationships in career decisions. Yet despite the compelling nature of Super's work, few researchers and practitioners in vocational psychology in the mid20th century (with certain notable exceptions, such as Luckey, 1974) sought to understand the dynamics of the familial influence. Nor has the call to examine the influence of family factors on youngsters' career choice behavior resulted in a significant increase in the empirical work on this issue. Instead, many vocational psychologists and career counselors have continued to operate on the assumption that people can make decisions which reflect their own dreams, passions, and talents in the world of work, unencumbered by family issues, cultural mores, racism, social class, or sexism.

\section{The current study}

According to Holland (1973), types influence types. More specifically, individuals' personality types influ- 
ence their way of life and the people they choose to affiliate with. Thus, parents facilitate the development of a personality type similar to their own in their children through the life environment they create. Indeed, Helwig (1984) examined the interrelationships of Holland types in three generations of one family and found evidence of similarity between parents and children. Following the same principle, parents can be expected to reward their offspring for exhibiting career interests that are similar to their own. Nevertheless, only a few studies have investigated the similarity in career choice between parents and their children. One recent study that examined this issue found partial congruence between parents' occupations and their children's career choices, Miller et al., 2003).

The current study therefore sought to expand our knowledge of the nature of parental influence on young people's career development by examining the relationships between the quality of the parent-offspring relationship on the one hand, and the similarity between the parents' careers and job characteristics and the preferences reported by their offspring for their future career on the other. The following hypotheses were formulated:

Hypothesis 1: A positive correlation will be found between the quality of the parent-offspring relationship and the similarity between the parents' careers and the preferred careers of their son/daughter.

Hypothesis 2: A positive correlation will be found between job characteristics that are judged important by the son/daughter (expectations of future career) and the perceived characteristics of their parents' jobs.

\section{Method}

\section{Participants}

The sample consisted of 280 respondents in Israel: $14612^{\text {th }}$ grade students $(52.1 \%)$ and 134 university students $(47.9 \%)$. Forty percent of the respondents were women; $80.7 \%$ were native-born Israelis and $19.3 \%$ were immigrants. In terms of age, $52 \%$ were under 18 years old, $19 \%$ were between $18-25,14 \%$ were between 26-30, and the rest were older.

\section{Measures}

\section{Independent variables}

Father-Child Exchange (FCX) was measured by means of the scale developed by Graen, Novak and Sommerkamp (1982) to tap the quality of the leadermember exchange (LMX) relationship, adapted for the relationship between father and son/daughter (as per- ceived by the latter). This instrument was chosen as we posited that the interaction between a father and his offspring can be construed to resemble that of superior and subordinate. The questionnaire consisted of 7 items (e.g., "My father understands my needs and difficulties"; "I have a good relationship with my father"). Participants responded to each statement on a 6-point Likert scale ranging from 1 (strongly disagree) to 6 (strongly agree). The internal consistency (Cronbach's alpha) of the 7 items was $0.863(M=4.53$; $S D=0.96)$ for the total sample, and $0.86(M=4.56$; $S D=0.94)$ and $0.87(M=4.49 ; S D=0.98)$ for highschool and university students respectively.

Mother-Child Exchange (MCX) was assessed using the same instrument and response scale as that described above for the father-child relationship, with the word "mother" replacing "father." The internal consistency was alpha $=0.87(M=4.94 ; S D=0.87)$ for the total sample, and alpha $=0.88(M=4.97 ; S D=$ $0.87)$ and alpha $=0.87(M=4.90 ; S D=0.88)$ for high school and university students, respectively.

Father's Job Characteristics, as perceived by the son/daughter, were measured by the 20 items of the Minnesota Satisfaction Questionnaire (MSQ; Weiss, Dawis, England, \& Lofquist, 1967), which can be regarded as a shorter version of the Minnesota Job Description Questionnaire (MJDQ) as it relates to the same work aspects. Respondents were asked to indicate the degree to which each of the items (e.g., "My father's job enables him to gain recognition for what he does") is an apt description or characteristic of his/her father's job, with answers marked on a 6-point Likert scale ranging from 1 (not at all descriptive/characteristic) to 6 (very descriptive/characteristic). The internal consistency of the instrument in the current study was alpha $=0.92(M=4.20 ; S D=0.96)$ for the total sample, and alpha $=0.91(M=4.25 ; S D=$ $0.91)$ and alpha $=0.93(M=4.15 ; S D=1.0)$, highschool students and university students, respectively.

Mother's Job Characteristics as perceived by the son/daughter was measured using the same questionnaire and response scale as described above for father's job characteristics, with the word "mother" replacing "father." The internal consistency was alpha $=0.92(M=3.99 ; S D=0.96)$ for the total sample, and alpha $=0.91(M=4.03 ; S D=0.96)$ and alpha $=0.93$ $(M=3.94 ; S D=0.96)$ for high-school and university students, respectively.

\section{Dependent Variables}

Offspring's Desired Job Characteristics were tapped using the same questionnaire and scale as those employed to gauge Father's/Mother's Job Charac teristics, with the necessary linguistic changes. The internal consistency was alpha $=0.80$ for the total sample, and alpha $=0.80(M=4.77 ; S D=0.48)$ and alpha $=$ 
Table 1. Differences in study variables between high-school and university students

\begin{tabular}{lccc}
\hline Variable & $\mathrm{F}(1,239)$ & $\mathrm{Sig}$ & $\begin{array}{r}\text { Hotelling } \\
\mathrm{T}^{2}\end{array}$ \\
\hline Quality of relationship with father & .17 & .67 & \\
Quality of relationship with mother & .57 & .45 & \\
Offspring's desired job characteristics & 1.39 & .24 & .02 \\
Father's job characteristics & 1.33 & .25 & \\
Mother's job characteristics & .76 & .38 & \\
\hline
\end{tabular}

served as the dependent (nominal dichotomous) variable, and the quality of the relationship with the father and with the mother as the independent variables. The results are presented in Table 2.

As Table 2 shows, no significant effect was found for the quality of the relationship with the father or the mother on the preferred career of their son or daughter. In the next stage of the analysis, Pearson and corrected point-biserial correlations were performed to examine the relationships between the career characteristics deemed important by the younger generation (desired

Table 2. Results of logistic regression of similarity of parent's and offspring's career choices

\begin{tabular}{lcccc}
\hline Variable & B & Wald & Sig & Model Summary \\
\hline Quality of relationship with father & -.15 & .65 & .41 & Cox \& Snell \\
Quality of relationship with mother & .02 & .01 & .91 & R Square $=.003$ \\
\hline
\end{tabular}

*Dependent variable: Fit of career choice $(1=$ different, $2=$ similar $)$

$0.81(M=4.83 ; S D=0.50)$ for high-school and university students, respectively.

Fit of Father's/Mother's Present Job and Offs pring's Preferred Job was measured by asking respondents to note their father's and mother's current jobs and the job he/she would like to have in the future. The responses were coded by two of the authors into two categories: similar and different. The coding was first done independently by each of the judges. A discussion then followed to settle the discrepancies until a consensus was reached. The results appear in Table 1. As can be seen, no differences were found between the two groups. Consequently, the statistical analyses were conducted on the sample as a whole.

A logistic regression model was then performed to examine the correlation between the quality of the parent-offspring relationship and the similarity between the parents' careers and their son/daughter's preferred career. The similarity of the offspring's preferred career to that of the career of one or both of the parents characteristics of his/her future career) and the perceived job characteristics of their parents. The results appear in Table 3.

As can be seen in Table 3, in line with our hypothesis, a positive correlation was found between the job characteristics desired by the son/daughter and the characteristics they judged to be descriptive of their parents' jobs. Furthermore, Gender identity was not found to be significant in the case of fathers and sons

Table 3 also reveals that no significant correlations were produced by the variable of professional fit except for offspring's desired characteristics.. We therefore decided to investigate this issue further by means of a logistic regression measure using similarity between preferred job and parents' jobs as the dependent variable (different/similar), and four independent variables: quality of relationship with father; quality of relationship with mother; correlation between father's perceived job characteristics and offspring's desired job characteristics; and correlation

Table 3. Pearson correlations between study variables

\begin{tabular}{|c|c|c|c|c|c|}
\hline & 2 & 3 & 4 & 5 & 6 \\
\hline 1. Quality of relationship with father & $.47 * *$ & $.21 * *$ & $.31 * *$ & $.21 * *$ & $\begin{array}{l}-.05 \\
(-.08)^{\mathrm{a}}\end{array}$ \\
\hline 2. Quality of relationship with mother & 1 & $.26 * *$ & $.17 * *$ & $.28 * *$ & $\begin{array}{l}-.02 \\
(-.03)^{\mathrm{a}}\end{array}$ \\
\hline 3. Offspring's desired job characteristics & & 1 & $.14^{*}$ & $.16^{*}$ & $\begin{array}{l}-.11 \\
(-.17 *)^{\mathrm{a}}\end{array}$ \\
\hline 4. Father's job characteristics & & & 1 & $.55^{* *}$ & $\begin{array}{l}.07 \\
(.11)^{\mathrm{a}}\end{array}$ \\
\hline 5. Mother's job characteristics & & & & 1 & $\begin{array}{c}-.04 \\
(-.06)^{\mathrm{a}}\end{array}$ \\
\hline 6. Fit of career choice $(1=$ different, $2=$ similar $)$ & & & & & 1 \\
\hline
\end{tabular}

${ }^{*} p<0.05 ; * * p<0.01$. a. Point-biserial correlations, corrected for attenuation owing to unequal sample size. 
between mother's perceived job characteristics and offspring's desired job characteristics. The analysis was conducted separately for the high-school students and the university students. The results are presented in Tables 4 (university students) and 5 (high school students).

As Table 4 indicates, no factors were found to predict the degree of similarity between either of the parents' careers and the university students' desired career. Among high school students (Table 5), however positive effects emerged for the correlation between the perceived characteristics of the father's job and the younger generation's desired job characteristics on the high-school student's preferred career. In other words, the higher the correlation between the father's job characteristics and the son/daughter's desired job characteristics, the more the high-school student's preferred career was likely to be similar to the father's career. The correlation with the characteristics of the mother's job produced a negative effect. That is, the higher the correlation between the perceived characteristics of the mother's job and the high-school student's desired job characteristics, the less the high-school student's preferred career tended to be similar to the mother's career.

\section{Discussion}

This study sought to examine whether the quality of the parent-offspring relationship affects the younger generation's preferences for their future career. The parents' influence on their children's career preferences was explored by means of two factors. The first was the dichotomous variable of "similarity in career choice," that is, whether the youngster's preferred future career was similar to or different from the careers of his/her parents. The second was job characteristics, or more specifically, the degree to which the job characteristics desired by the youngster were also perceived to be descriptive of the parents' jobs.

Contrary to our hypothesis, no significant relation was found between the quality of the relationship with the father or mother and similarity between the youngster's preferred career and the parents' careers. This might be explained by the use of a dichotomous variable which allowed little room for nuances of similarity. In other words, although the jobs themselves might be different, they may share certain features. Furthermore, over half of the respondents in this study were high-school students, who may yet not have formulated their professional career plan (Nevill \& Super, 1986).

Our second hypothesis related to job characteristics, which we believe may better reflect the influence of the quality of the parent-offspring relationship on the youngster's career preferences. Indeed, among young people reporting a good relationship with their parents, a positive correlation was found between job characteristics deemed important by the son/daughter and the characteristics they perceived to be descriptive of their parents' jobs. This would seem to indicate that a close supportive relationship between parents and their offspring may encourage the younger generation to seek features in their future job that are similar to those which they believe to characterize their parents' jobs.

This is consistent with previous findings which suggest that the choice of a future career track is not just a function of individual development, but also a result of a youngster's relationship with his/her family and the degree to which the parents grant their offspring autonomy, support, and increasing independence, and allow them to freely explore career options. Our findings therefore support the view that parents play a major role in their offspring's career development (Miller et al., 2003).

Certain limitations of this study should be noted. First, the instrument used to examine the quality of the

Table 4. Results of logistic regression of similarity in career choice among university students

\begin{tabular}{lcccc}
\hline Variable & B & Wald & Sig & Model Summary \\
\hline Quality of relationship with father & .28 & .56 & .45 & Cox \& Snell \\
Quality of relationship with mother & -.19 & .26 & .61 & R Square =.015 \\
Correlation of father-offspring job characteristics fit & .21 & .21 & .64 & .81 \\
Correlation of mother-offspring job characteristics fit & .10 & .06 & \\
\hline
\end{tabular}

Table 5 Results of logistic regression of similarity in career choice among high school students

\begin{tabular}{lcccc}
\hline Variable & B & Wald & Sig & Model Summary \\
\hline Quality of relationship with father & -.10 & .10 & .75 & Cox \& Snell \\
Quality of relationship with mother & .23 & .53 & .47 & $.02^{*}$ \\
Correlation of father-offspring job characteristics fit & 1.20 & 5.33 & $.05^{*}$ \\
Correlation of mother-offspring job characteristics fit & -.67 & 1.35 & .06 \\
\hline
\end{tabular}

${ }^{*} \mathrm{p}<0.05$ 
parent-offspring relationship may not have ideally reflected the family relationship. Our questionnaire was adapted from a scale relating to LMX (Graen et al., 1982), on the assumption that the interaction between parents and their children can be said to resemble the interaction between superior and subordinate. Future studies might attempt to replicate our results using different measures of the quality of the parent-offspring relationship. Secondly, our sample consisted of high-school and university students. In terms of development, however, 18-year-olds and 25year-olds are not the same people and do not maintain the same sort of relationship with their parents, and these differences may have affected the results. More reliable results might be obtained by using a longitudinal design to examine various stages in the family relationship, as well as the trajectory of its link to career choice development. Thirdly, the high-school students in our sample all came from the same school. A representative sample of students from various schools and/or towns might have produced different results. Finally, there might be a question as to whether teenagers can accurately assess the characteristics of their parents' jobs, as contact with parents during adolescence may often be confrontational or distant.

To conclude, our study indicates that parents' impact on young people's career choices may be mediated by the quality of the parent-offspring relationship. The results suggest that a closer relationship may induce youngsters to opt for a job whose characteristics are similar to those of their parents' careers. This appears to be true particularly in the case of mothers and daughters.

In view of these findings, it would be interesting to further explore the dynamics of parents' influence on youngsters' career choices, particularly in light of the changes in the family in modern society. Krau (2009) contends that the family structure and parental authority are being eroded, leading to diminished family influence on children in respect to values, boundaries, education and morality. Instead, he claims, the family is being replaced by the "Internet society." Future studies might therefore examine whether parental influence on career choice has declined in contemporary society, and whether or not it is affected by use of the Internet.

Furthermore, the power of the peer group is especially strong in adolescence, when many youngsters rely primarily on information from friends. However, scant research attention has been devoted to the influence of the peer group, as compared to that of the parents, on career choice.

In sum, the current study provides further evidence of the impact of the family on the younger generation's career preferences. Further research is required before we can fully understand the dynamics of this influence, and how it may be evolving in the contemporary era of rapid social change.

\section{References}

Blustein, D. L. (2004). Moving from the inside out: Further explorations of the family of origin/career development linkage. The Counseling Psychologist, 32, 603-611.

Blustein, D. L., Walbridge, M. M., Friedlander, M. L., \& Palladino, D. E. (1991). Contributions of psychological separation and parental attachment to the career development process. Journal of Counseling Psychology, 38, 39-50.

Chope, R. C. (2005). Qualitatively assessing family influence in career decision making. Journal of Career Assessment, 13, 395-414.

Crockett, L. J., \& Bingham, C. R. (2000). Anticipating adulthood: Expected timing of work and family transitions among rural youth. Journal of Research on Adolescence, $10,151-172$.

Dietrich, J., \& Kracke, B. (2009). Career-specific parental behaviors in adolescents' development. Journal of Vocational Behavior, 75, 109-119.

Felsman, D. E., \& Blustein, D. L. (1999). The role of peer relatedness in late adolescent career development. Journal of Vocational Behavior, 54, 279-295.

Graen, J. B., Novak, M., \& Sommerkamp, P. (1982). The effects of leader-member exchange and job design on productivity and satisfaction: Testing a dual attachment model. Organizational Behavior and Human Performance, 30, 109-131.

Grotevant, H. D., \& Cooper, C. R. (1988). The role of family experience in career exploration - A life-span perspective. Life-Span Development and Behavior, 8, 231-258.

Guay, F., Senecal, C., Gauthier, L., \& Fernet, C. (2003). Predicting career indecision: A self-determination theory perspective. Journal of Counseling Psychology, 50, 165177.

Hargrove, B. K., Creagh, M. G., \& Burgess, B. L. (2002). Family interaction patterns as predictors of vocational identity and career decision-making self-efficacy. Journal of Vocational Behavior, 61, 185-201.

Hargrove, B. K., Inman, A. G., \& Crane, R. L. (2005). Family interaction patterns, career planning attitudes, and vocational identity of high school adolescents. Journal of Career Development, 31, 263-278.

Helwig, A. A. (1984). A family case study using Holland types. AMHCA Journal, 6, 88-97.

Holland, J. L. (1973). Making vocational choice: A theory of careers. Englewood Cliffs, NJ: Prentice-Hall.

Johnson, P., Buboltz, W. C., \& Nichols, C. N. (1999). Parental divorce, family functioning, and vocational identity of college students. Journal of Career Development, 26, 137-146.

Ketterson, T. U., \& Blustein, D. L. (1997). Attachment relationships and the career exploration process. Career Development Quarterly, 46, 167-178.

Kracke, B. (1997). Parental behaviors and adolescents' career exploration. Career Development Quarterly, 45, 341-350.

Krau, E. (1997). The realization of life aspirations through vocational careers. Westport, CT: London. 
Krau, E. (2009). Toward globalization with a human face. Lanham, MD: University Press of America.

Lamborn, S., Mounts, N., Steinberg, L., \& Dornbusch, S. (1991). Patterns of competence and adjustment among adolescents from authoritative, authoritarian, indulgent and neglectful homes. Child Development, 62, 10491065 .

Larson, J. H. (1995). The use of family systems to explain and treat decision problems in late adolescence: A review. The American Journal of Family Therapy, 23, 328-337.

Lim, V. K. G., \& Loo, G. L. (2003). Effects of parental job insecurity and parenting behaviors on youth's self-efficacy and work attitudes. Journal of Vocational Behavior, 63, 86-98.

Lopez, F. G., \& Andrews, S. (1987). Career indecision: A family systems perspective. Journal of Counseling and Development, 65, 304-307.

Luckey, E. B. (1974). The family: Perspectives on its role in development and choice. In E.L. Herr (Ed.), Vocational guidance and human development (pp. 203-231). Boston: Houghton Mifflin.

Miller, M. J., Wells, D., Springer, T. P., \& Cowger, E., Jr. (2003). Do types influence types? Examining the relationship between students' and parents' Holland codes. College Students Journal, 37, 190-193.

Mortimer, J. T., Zimmer-Gembeck, M. J., Holmes, M., \& Shanahan, M. J. (2002). The process of occupational decision making: Patterns during the transition to adulthood. Journal of Vocational Behavior, 61, 439.

Nevill, D. D., \& Super, D. E. (1986). The salience inventory: Theory, application and research. Palo Alto, CA: Consulting Psychologists Press.

Noller, P. (1994). Relationships with parents in adolescence. Process and outcome. In R. Montemayor, G. R. Adams, \& T. P. Gullotta (Eds.), Personal relationships during adolescence. Thousands Oaks, CA: Sage Publications.

O’Brien, K. M. (1996). The influence of psychological separation and parental attachment on the career development of adolescent women. Journal of Vocational Behavior, 28, 257-274.

Otto, L. B. (2000). Youth perspectives on parental career influence. Journal of Career Development, 27, 111-118.

Palladino-Schultheiss, D. E., \& Blustein, D. L. (1994). Role of adolescent-parent relationships in college student development and adjustment. Journal of Counseling Psychology, 41, 248-255.

Phillips, S. D., Blustein, D. L., Jobin-Davis, K., \& White, S. F. (2002). Preparation for the school-to-work transition: The views of high school students. Journal of Vocational Behavior, 61, 202-216.

Phillips, S. D., Christopher-Sisk, E. K., \& Gravino, K. L.
(2001). Making career decisions in a relational context. Counseling Psychologist, 29, 193-213.

Rainey, L. M., \& Borders, L. D. (1997). Influential factors in career orientation and career aspiration of early adolescent girls. Journal of Counseling Psychology, 44, 160-172.

Robertson, L. (1990). Functions of work meaning in organizations: Work meaning and work motivation. In A. P. Brief \& W. R. Nord (Eds.), Meanings of occupational work: A collection of essays (pp. 107-134). Lexington, MA: Lexington Books.

Rogers, C. R. (1978). Carl Rogers on personal power. London: Constable \& Co.

Ryan, N. E., Solberg, V. S., \& Brown, S. D. (1996). Family dysfunction, parental attachment, and career search selfefficacy among community college students. Journal of Counseling Psychology, 43, 84-89.

Schultheiss, D. E. P., Kress, H. M., Manzi, A. J., \& Glasscock, M. J. (2001). Relational influences in career development: A qualitative inquiry. Counseling Psychologist, 29, 214-239.

Super, D. E. (1957). The psychology of careers. New York: Harper \& Row.

Super, D. E. (1990). A life-space approach to career development. In: D. Brown \& L. Brooks (Eds.), Career choice and development: Applying contemporary theories to practice (pp 197-261), San Francisco: Jossey-Bass.

Tang, M., Fouad, N. A., \& Smith, P. L. (1999). Asian Americans' career choices: A path model to examine factors influencing their career choices. Journal Vocational Behavior, 54, 142-157.

Tracey, T. J. G., Lent, R. W., Brown, S. D., Soresi, S., \& Nota, L. (2006). Adherence to RIASEC structure in relation to career exploration and parenting style: Longitudinal and idiothetic considerations. Journal of Vocational Behavior, 69, 248-261.

Vignoli, E., Croity-Belz, S., Chapeland, V., de Fillipis, A., \& Garcia, M. (2005). Career exploration in adolescents: The role of anxiety, attachment, and parenting style. Journal of Vocational Behavior, 67, 153-168.

Wahl, K. H., \& Blackhurst, A. (2000). Factors affecting the occupational and educational aspirations of children and adolescents. Professional School Counseling, 3, 367-374.

Wall, J., Covell, K., \& Maclntyre, P. D. (1999). Implications of social supports for adolescents' education and career aspirations. Canadian Journal of Behavioral Science, 31, 63-71.

Weiss, D. J., Dawis, R. V., England, G. H., \& Lofquist, L.H. (1967). Manual for the Minnesota Satisfaction Questionnaire. Minnesota Studies in Vocational Rehabilitation, XXII.

Young, R. (1994). Helping adolescents with career development: The active role of parents. The Career Development Quarterly, 42, 195-203.

Manuscript received: 20/11/2012 Revision received: 16/01/2012 Accepted: 17/01/2012 